\title{
2-Aminoethoxydiphenyl Borate as a Prototype Drug for a Group of Structurally Related Calcium Channel Blockers in Human Platelets
}

Yuliya Dobrydneva

Christopher J. Abelt

Beth Dovel

Celina M. Thadigiri

Roy L. Williams

Old Dominion University

See next page for additional authors

Follow this and additional works at: https://digitalcommons.odu.edu/chemistry_fac_pubs

Part of the Biochemistry Commons, Molecular Biology Commons, and the Pharmacology Commons

\section{Repository Citation}

Dobrydneva, Yuliya; Abelt, Christopher J.; Dovel, Beth; Thadigiri, Celina M.; Williams, Roy L.; and Blackmore, Peter F., "2-Aminoethoxydiphenyl Borate as a Prototype Drug for a Group of Structurally Related Calcium Channel Blockers in Human Platelets" (2006). Chemistry \& Biochemistry Faculty Publications. 133.

https://digitalcommons.odu.edu/chemistry_fac_pubs/133

\section{Original Publication Citation}

Dobrydneva, Y., Abelt, C. J., Dovel, B., Thadigiri, C. M., Williams, R. L., \& Blackmore, P. F. (2006). 2-aminoethoxydiphenyl borate as a prototype drug for a group of structurally related calcium channel blockers in human platelets. Molecular Pharmacology, 69(1), 247-256. doi:10.1124/mol.105.015701 
Authors

Yuliya Dobrydneva, Christopher J. Abelt, Beth Dovel, Celina M. Thadigiri, Roy L. Williams, and Peter F. Blackmore 


\title{
2-Aminoethoxydiphenyl Borate as a Prototype Drug for a Group of Structurally Related Calcium Channel Blockers in Human Platelets
}

\author{
Yuliya Dobrydneva, Christopher J. Abelt, Beth Dovel, Celina M. Thadigiri, Roy L. Williams, \\ and Peter F. Blackmore \\ Department of Physiological Sciences, Eastern Virginia Medical School, Norfolk, Virginia (Y.D., P.F.B.); Department of \\ Chemistry and Biochemistry, Old Dominion University, Norfolk, Virginia (B.D., C.M.T., R.L.W.); and Department of Chemistry, \\ The College of William and Mary, Williamsburg, Virginia (C.J.A.)
}

Received June 15, 2005; accepted October 7, 2005

\section{ABSTRACT}

We have synthesized a series of 2-aminoethoxydiphenyl borate (2-APB, 2,2-diphenyl-1,3,2-oxazaborolidine) analogs and tested their ability to inhibit thrombin-induced $\mathrm{Ca}^{2+}$ influx in human platelets. The analogs were either synthesized by adding various substituents to the oxazaborolidine ring (methyl, dimethyl, tert-butyl, phenyl, methyl phenyl, and pyridyl) or increasing the size of the oxazaborolidine ring to seven- and nine-membered rings. NMR analysis of the boron-containing analogs suggests that each of them exist as a ring structure through the formation of an $\mathrm{N} \rightarrow \mathrm{B}$ coordinate bond (except for the hexyl analog). The possibility that these boron-containing compounds formed dimers was also considered. All compounds dose-dependently inhibited thrombin-induced $\mathrm{Ca}^{2+}$ in- flux in human platelets, with the 2,2-diphenyl-1,3,2-oxazaborolidine-5-one derivative having the weakest activity at $100 \mu \mathrm{M}$, whereas the $(S)$-4-benzyl and $(R)$-4-benzyl derivatives of 2-APB were approximately 10 times more potent than the parent 2-APB. Two nonboron analogs (3-methyl and 3-tert-butyl 2,2diphenyl-1,3-oxazolidine) were synthesized; they had approximately the same activity as 2-APB, and this implies that the presence of boron was not necessary for inhibitory activity. All of the compounds tested were also able to inhibit thrombininduced calcium release. We concluded that extensive modifications of the oxazaborolidine ring in 2-APB can be made, and $\mathrm{Ca}^{2+}$-blocking activity was maintained.
2-Aminoethoxydiphenyl borate (2-APB; systematic name: 2,2-diphenyl-1,3,2-oxazaborolidine, compound 1) was originally described as an inhibitor of inositol 1,4,5-trisphosphate receptors $\left(\mathrm{IP}_{3} \mathrm{R}\right)$ in a variety of cells (Maruyama et al., 1997) and has been extensively used as a probe for examining calcium influx processes. 2-APB was inappropriately used in several studies to imply that $\mathrm{IP}_{3} \mathrm{Rs}$ were involved in storeoperated $\mathrm{Ca}^{2+}$ entry (SOCE) (Ma et al., 2000; van Rossum et al., 2000). For a review of our current understanding of the

The laboratory of P.F.B. was supported by grants from The Jeffress Memorial Trust and The Commonwealth Health Research Board. Y.D. received support from American Association of University Women Educational Foundation and the United States Department of Agriculture.

Some of the findings in this manuscript were presented at two meetings of the Virginia Academy of Science (Dovel et al., 2002; Thadigiri et al., 2003) and at Experimental Biology (Dobrydneva et al., 2001, 2002).

Article, publication date, and citation information can be found at http://molpharm.aspetjournals.org.

doi:10.1124/mol.105.015701. nature of SOCE and how the SOCE channels are regulated, see Parekh and Putney (2005). It has been suggested that SOCE is mediated by members of the transient receptor potential canonical (TRPC), family although this has not been accepted universally (Parekh and Putney, 2005).

Upon further investigation, it became evident that 2-APB, along with inhibition of $\mathrm{IP}_{3} \mathrm{Rs}$, was also inhibiting SOCE directly in several cell types (Bakowski et al., 2001; Braun et al., 2001; Broad et al., 2001; Diver et al., 2001; Dobrydneva and Blackmore, 2001; Dobrydneva et al., 2001, 2002; Gregory et al., 2001; Iwasaki et al., 2001; Ma et al., 2001; Prakriya and Lewis, 2001; Bootman et al., 2002). The inhibition of SOCE seemed to be at an extracellular site by a mechanism not involving intracellular $\mathrm{IP}_{3} \mathrm{Rs}$. In our study showing that 2-APB blocked SOCE in human platelets (Dobrydneva and Blackmore, 2001), we tested whether several other structurally related compounds were also inhibitors of SOCE. We

ABBREVIATIONS: 2-APB, 2-aminoethoxydiphenyl borate; SOCE, store-operated $\mathrm{Ca}^{2+}$ entry; SERCA, sarcoplasmic/endoplasmic reticulum calcium ATPase; TRPC, transient receptor potential canonical; TRPV, transient receptor potential vanilloid; TRPM, transient receptor potential melastatin; $\mathrm{N} \rightarrow \mathrm{B}$, nitrogen boron coordinate bond; $d_{6}$-DMSO, deuterated dimethyl sulfoxide; $\mathrm{IP}_{3} \mathrm{R}, 1,4,5$-trisphosphate receptor; AM, acetoxymethyl ester. 
found that the nonboron analog of 2-APB, 2,2-diphenyltetrahydrofuran, and diphenylboronic anhydride also inhibited both calcium mobilization and calcium influx (Dobrydneva and Blackmore, 2001). Two other nonboron analogs, phenytoin and diphenhydramine, were very weak inhibitors of calcium influx. From this limited structural analysis, it seemed that compounds with calcium-blocking activity possessed diphenyl groups; also, the presence of a saturated five-membered ring structure was needed. The presence of boron in the structure was not an absolute requirement, although boron and nitrogen were necessary for ring formation through an $\mathrm{N} \rightarrow \mathrm{B}$ coordinate bond (Fig. 1). It has also been proposed that 2-APB forms a dimer (Fig. 1) (van Rossum et al., 2000). 2-APB, at high concentrations, has also been shown to activate TRPV1, TRPV2, and TRPV3, three heat-gated members of the transient receptor potential vanilloid ion-channel subfamily ( $\mathrm{Hu}$ et al., 2004). 2,2-Diphenyltetrahydrofuran and diphenylboronic anhydride (Dobrydneva and Blackmore, 2001) were also able to modulate the activity of these channels (Chung et al., 2005).

The calcium channel responsible for store-mediated calcium entry in human platelets is believed to be TRPC1 (Brownlow and Sage, 2003). The regulation of this entry process seems to be very complex and possibly involves the conformational coupling between the $\mathrm{IP}_{3} \mathrm{R}$ in the endoplasmic reticulum and the store-operated calcium channels located in the plasma membrane (Rosado and Sage, 2005). There is evidence for the involvement of synaptosome-associated protein-25, pp60 $0^{s r c}$, the actin cytoskeleton, and extracellular regulated kinase in this process (Rosado and Sage, 2001, 2004a,b; Redondo et al., 2004). Patch-clamp experiments have shown that 2-APB acts extracellularly on various TRP channels (Xu et al., 2005), so it reasonable to assume that 2-APB also acts extracellularly on TRPC1 in platelets. However, 2-APB could also be interacting with any of the other components that regulate TRPC1 activity such as extracellular regulated kinase, pp60 ${ }^{\text {src }}$, and synaptosome-asso-

\section{2-APB ring form}

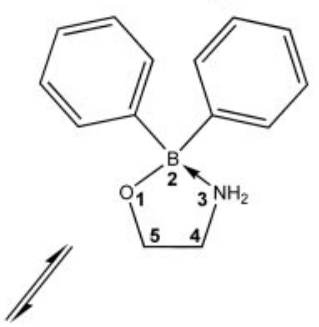

2-APB open chain form
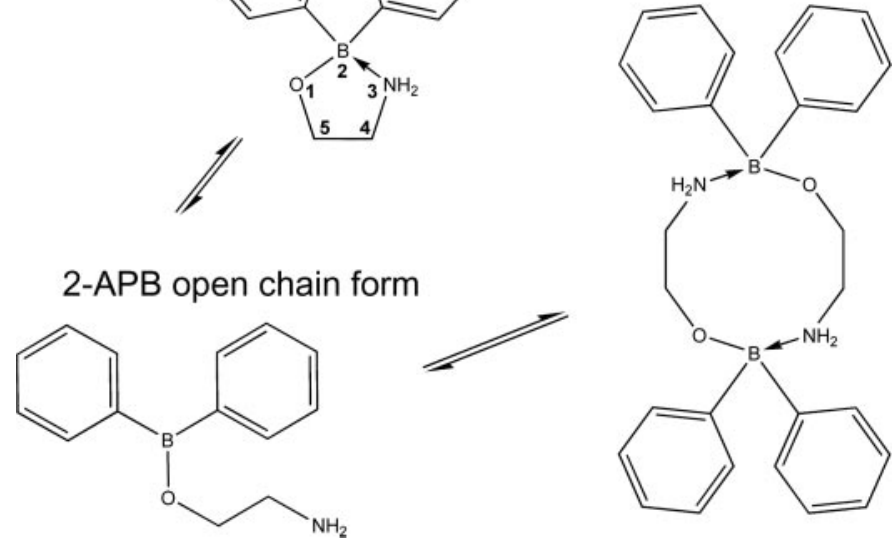

Fig. 1. Structures of 2-APB: open-chain form, five-membered $(1,3,2$ oxazaborolidine) ring form created when an $\mathrm{N} \rightarrow \mathrm{B}$ coordinate bond is formed, and dimeric form produced when two $\mathrm{N} \rightarrow \mathrm{B}$ coordinate bonds are formed between two molecules of 2-APB. Dimeric 2-APB could also exist with the formation of only one $\mathrm{N} \rightarrow \mathrm{B}$ coordinate bond (structure not shown). ciated protein-25 (Rosado and Sage, 2001, 2004a,b; Redondo et al., 2004).

The aim of the present study was to synthesize a series of boron-containing and nonboron-containing analogs of 2-APB to determine whether we could obtain compounds more potent than the parent 2 -APB at inhibiting $\mathrm{Ca}^{2+}$ influx in human platelets. We anticipated that this series of compounds would shed light onto the structure of the pharmacophore that was responsible for calcium-blocking activity. We succeeded in synthesizing several analogs that were as effective as the parent 2-APB, and two boron-containing compounds that were more potent than 2 -APB at inhibiting $\mathrm{Ca}^{2+}$ influx in platelets.

\section{Materials and Methods}

Materials. The following were obtained from Sigma-Aldrich (St. Louis, MO): 2-aminoethoxydiphenyl borate, 2-(methylamino)ethanol, 2-( $t$-butylamino)ethanol, 2-amino-1-phenylethanol, 4-amino-1butanol, 6-amino-1-hexanol, diphenylborinic anhydride, the sodium salt of glycine, ethanolamine, dimethyl sulfoxide, benzophenone, phosphorus pentachloride, and EGTA. 3,3-Diphenyl dihydrofuran-2one (trivial name: $\alpha, \alpha$-diphenyl- $\gamma$-butyrolactone) was from Acros Organics (Fairlawn, NJ). All organic solvents were from Fisher Scientific Co. (Pittsburgh, PA). Fura-2/AM was from Invitrogen (Carlsbad, CA).

Synthesis of 2-APB Analogs. All melting points were determined with a Thomas Hoover Capillary Melting Point Apparatus (Thomas Scientific, Swedesboro, NJ) and are uncorrected. ${ }^{1} \mathrm{H}$ NMR spectra were determined in a UnityPlus- $400 \mathrm{MHz}$ instrument operating at a field strength of $399.89 \mathrm{MHz}$ or a Varian Mercury Vx-400 spectrometer (Varian, Inc., Palo Alto, CA). All carbon, hydrogen, and nitrogen analyses were performed by Desert Analytics (Tucson, AZ). A general method was developed for the synthesis of 2-APB and the various 2-APB analogs, which is described for each compound. The method involved a reaction between diphenylborinic anhydride and a corresponding amino alcohol. The synthesis of 2,2-diphenyl-1,3,2oxazaborolidine (1) and ( $S$ )-4-benzyl-2,2-diphenyl-1,3,2-oxazaborolidine (11) are shown in Fig. 2. All of the reaction solutions were allowed to stir in an ice bath until precipitation occurred (no more than $1 \mathrm{~h}$ ), then they were chilled in an ice bath undisturbed for an additional $15 \mathrm{~min}$, which increased the amount of precipitation. All of the products were purified by recrystallization using ethyl acetate as the solvent, except for 2,2,5-triphenyl-1,3,2-oxazaborolidine (8), which was recrystallized using benzene. All of the products were white solids with sharp melting points. Monomeric structures with an internal $\mathrm{N} \rightarrow \mathrm{B}$ coordinate bond are shown for all compounds synthesized (Fig. 3). Because we have depicted 2-APB and its derivatives as ring structures in this study, then the commonly used name 2-aminoethoxydiphenyl borate does not describe this ring system. We have therefore used the 1983 IUPAC Hantzsch-Widman system to name the ring forms of 2-APB and its derivatives. The numbering order of the heteroatoms in the oxazaborolidine ring is oxygen number 1 , nitrogen number 2 , and boron number 3 ; hence, the numbering of this ring is 1,3,2-oxazaborolidine in 2-APB.

2,2-Diphenyl-1,3,2-oxazaborolidine (1). Ethanolamine (0.02 g) was added to $0.10 \mathrm{~g}$ of diphenylborinic anhydride in $4 \mathrm{ml}$ of acetonitrile. The solution was stirred for $1 \mathrm{~h}$ without any signs of precipitation. The solution was refrigerated for $15 \mathrm{~h}$ in which the product precipitated and was filtered to give $0.056 \mathrm{~g}$ of compound 1 ( $75 \%$ yield). The melting point was 193 to $194^{\circ} \mathrm{C}$ (literature, $190-192^{\circ} \mathrm{C}$ ). ${ }^{1} \mathrm{H}$ NMR $\left(d_{6}\right.$-DMSO): $2.83\left(\mathrm{p}, \mathrm{CH}_{2}\right), 3.77\left(\mathrm{CH}_{2}\right), 6.07$ (broad t, $\left.\mathrm{NH}_{2}\right)$, $7.01(\mathrm{~m}, 2 \mathrm{H}), 7.14(\mathrm{~m}, 4 \mathrm{H})$, and $7.39(\mathrm{~m}, 4 \mathrm{H})$. The broad triplet at 6.07 caused by the $\mathrm{NH}_{2}$ rapidly exchanged with the addition of $\mathrm{D}_{2} \mathrm{O}$.

3-Methyl-2,2-diphenyl-1,3,2-oxazaborolidine (2). 2-Methylaminoethanol $(0.05 \mathrm{~g})$ was added to $0.20 \mathrm{~g}$ of diphenylborinic anhy- 

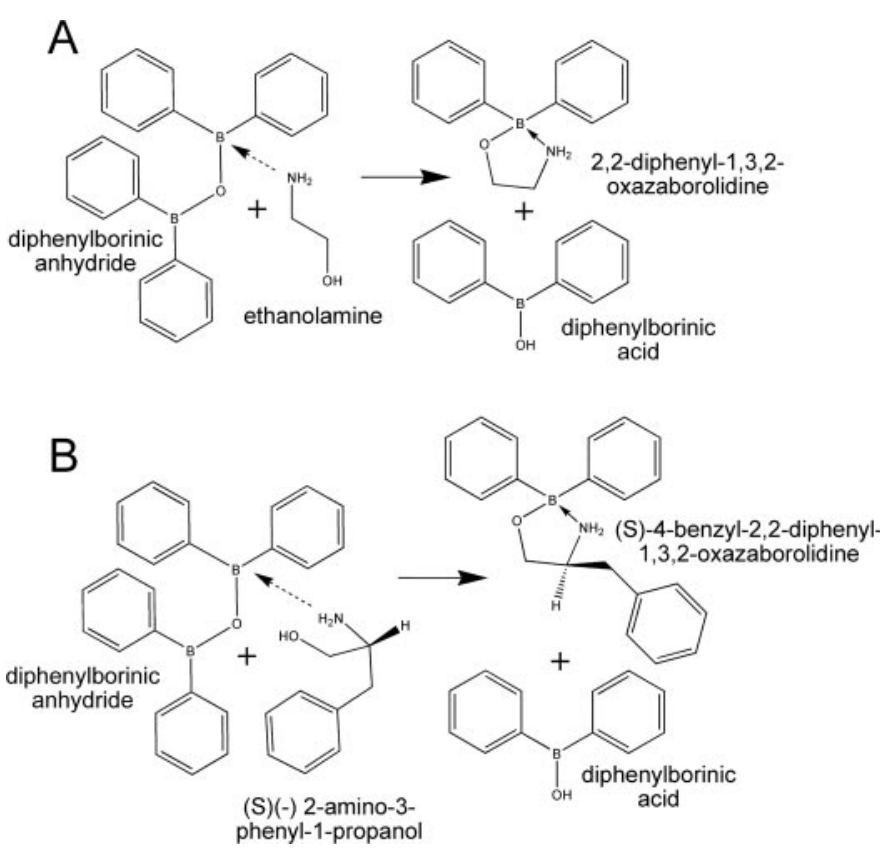

Fig. 2. The general scheme for the synthesis of the diphenyl oxazaborolidine analogs is shown. Two examples are shown. A, the synthesis of the parent 2,2-diphenyl-1,3,2-oxazaborolidine (1) is shown, and the starting reactants are diphenylborinic anhydride and ethanolamine. B, the synthesis of $(S)$-4-benzyl-2,2-diphenyl-1,3,2-oxazaborolidine (11) is shown, and the starting reactants in this synthesis are diphenylborinic anhydride and $(S)(-) 2$-amino-3-phenyl-1-propanol.

dride in $8 \mathrm{ml}$ of acetonitrile. The product precipitated to give $0.066 \mathrm{~g}$ of compound 2 (46\% yield); melting point, 196 to $197.5^{\circ} \mathrm{C} .{ }^{1} \mathrm{H} \mathrm{NMR}$ $\left(d_{6}\right.$-DMSO): $\delta 2.16\left(\mathrm{~d}, \mathrm{CH}_{3}\right), 2.64(\mathrm{p}, \mathrm{CH}), 3.03(\mathrm{p}, \mathrm{CH}), 3.75(\mathrm{q}, \mathrm{CH})$, $4.01(\mathrm{q}, \mathrm{CH}), 6.67(\mathrm{~m}, \mathrm{NH}), 7.09(\mathrm{t}, 2 \mathrm{H}), 7.16(\mathrm{t}, 4 \mathrm{H})$, and $7.46(\mathrm{dd}$, $4 \mathrm{H})$. Analysis: calculations for $\mathrm{C}_{15} \mathrm{H}_{18} \mathrm{BNO}$ : C, 75.33; $\mathrm{H}, 7.60 ; \mathrm{N}, 5.86$; found, C, 75.32; H, 7.56; N, 5.68. The multiplet at 6.67 was for the $\mathrm{NH}$ rapidly exchanged with the addition of $\mathrm{D}_{2} \mathrm{O}$.

3,3-Dimethyl-2,2-diphenyl-1,3,2-oxazaborolidine (3). Diphenylborinic anhydride $(0.01 \mathrm{~g})$ was stirred with $0.05 \mathrm{ml}$ of dimethylaminoethanol in $10 \mathrm{ml}$ of acetonitrile. The product slowly precipitated from solution to give $0.195 \mathrm{~g}$ of compound 3 ( $82 \%$ yield); melting point, 165 to $166^{\circ} \mathrm{C} .{ }^{1} \mathrm{H} \mathrm{NMR}\left(d_{6}-\mathrm{DMSO}\right): 2.50\left(\mathrm{~s}, 6 \mathrm{H}, \mathrm{CH}_{3}\right), 2.92(\mathrm{t}$, $\left.\mathrm{CH}_{2}\right), 4.10\left(\mathrm{t}, \mathrm{CH}_{2}\right), 7.10(\mathrm{~m}, 2 \mathrm{H}), 7.18(\mathrm{~m}, 4 \mathrm{H})$, and $7.65(\mathrm{~m}, 4 \mathrm{H})$.

3-tert-Butyl-2,2-diphenyl-1,3,2-oxazaborolidine (4). 2-tertButylaminoethanol $(0.07 \mathrm{~g})$ was added to $0.20 \mathrm{~g}$ of diphenylborinic anhydride in $8 \mathrm{ml}$ of acetonitrile. The product precipitated to give $0.125 \mathrm{~g}$ of compound 4 (76\% yield); melting point, 133.1 to $134.0^{\circ} \mathrm{C} .{ }^{1} \mathrm{H}$ NMR ( $d_{6}$-DMSO): $\delta 1.16\left(\mathrm{~s}, \mathrm{CH}_{3}\right), 2.69\left(\mathrm{t}, \mathrm{CH}_{2}\right), 3.55\left(\mathrm{t}, \mathrm{CH}_{2}\right), 6.91(\mathrm{tt}$, $\mathrm{NH}), 6.98(\mathrm{t}, 2 \mathrm{H}), 7.06(\mathrm{t}, 4 \mathrm{H}), 7.44(\mathrm{dd}, 4 \mathrm{H})$. Analysis: calculations for $\mathrm{C}_{18} \mathrm{H}_{24}$ BNO: C, 73.85; H, 8.62; N, 4.31; found: C, 73.31; H, 8.76; $\mathrm{N}, 4.68$. The peak at 6.91 , assigned to the $\mathrm{NH}$, rapidly exchanged with the addition of $\mathrm{D}_{2} \mathrm{O}$.

2,2,5-Triphenyl-1,3,2-oxazaborolidine (5). 2-Amino-1-phenylethanol $(0.08 \mathrm{~g})$ was added to $0.20 \mathrm{~g}$ of diphenylborinic anhydride in $8.0 \mathrm{ml}$ of acetonitrile. The product precipitated to give $0.072 \mathrm{~g}$ of compound 5 (41\% yield); melting point, 194.9 to $196.0^{\circ} \mathrm{C} .{ }^{1} \mathrm{H}$ NMR $\left(d_{6}\right.$-DMSO): $\delta 3.25\left(\mathrm{q}, \mathrm{CH}_{2}\right), 4.85(\mathrm{dd}, \mathrm{CH}), 6.31\left(\mathrm{t}, \mathrm{NH}_{2}\right), 7.03(\mathrm{t}, 2 \mathrm{H})$, $7.08(\mathrm{t}, 4 \mathrm{H}), 7.16(\mathrm{dd}, 4 \mathrm{H}), 7.25(\mathrm{t}, 2 \mathrm{H}), 7.34(\mathrm{t}, 4 \mathrm{H}), 7.49(\mathrm{dd}, 4 \mathrm{H})$. Analysis: calculations for $\mathrm{C}_{20} \mathrm{H}_{20} \mathrm{BNO}$ : C, 79.75; H, 6.69; N, 4.65; found, $\mathrm{C}, 80.27 ; \mathrm{H}, 6.62 ; \mathrm{N}, 4.65$. The triplet peak at 6.31 rapidly exchanged with the addition of $\mathrm{D}_{2} \mathrm{O}$.
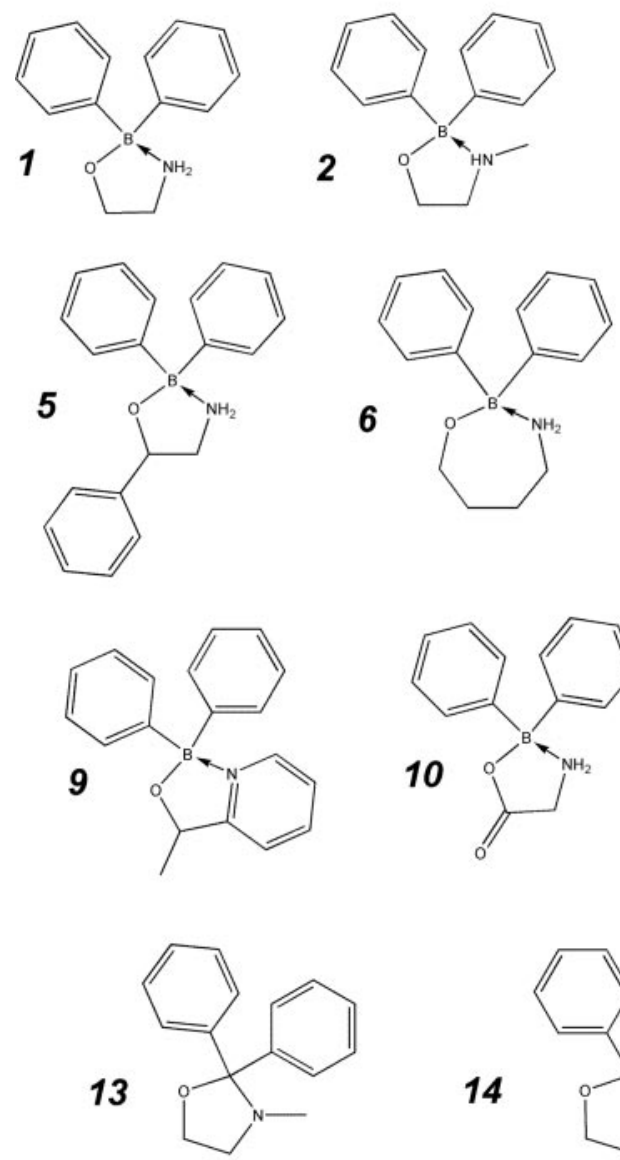

14
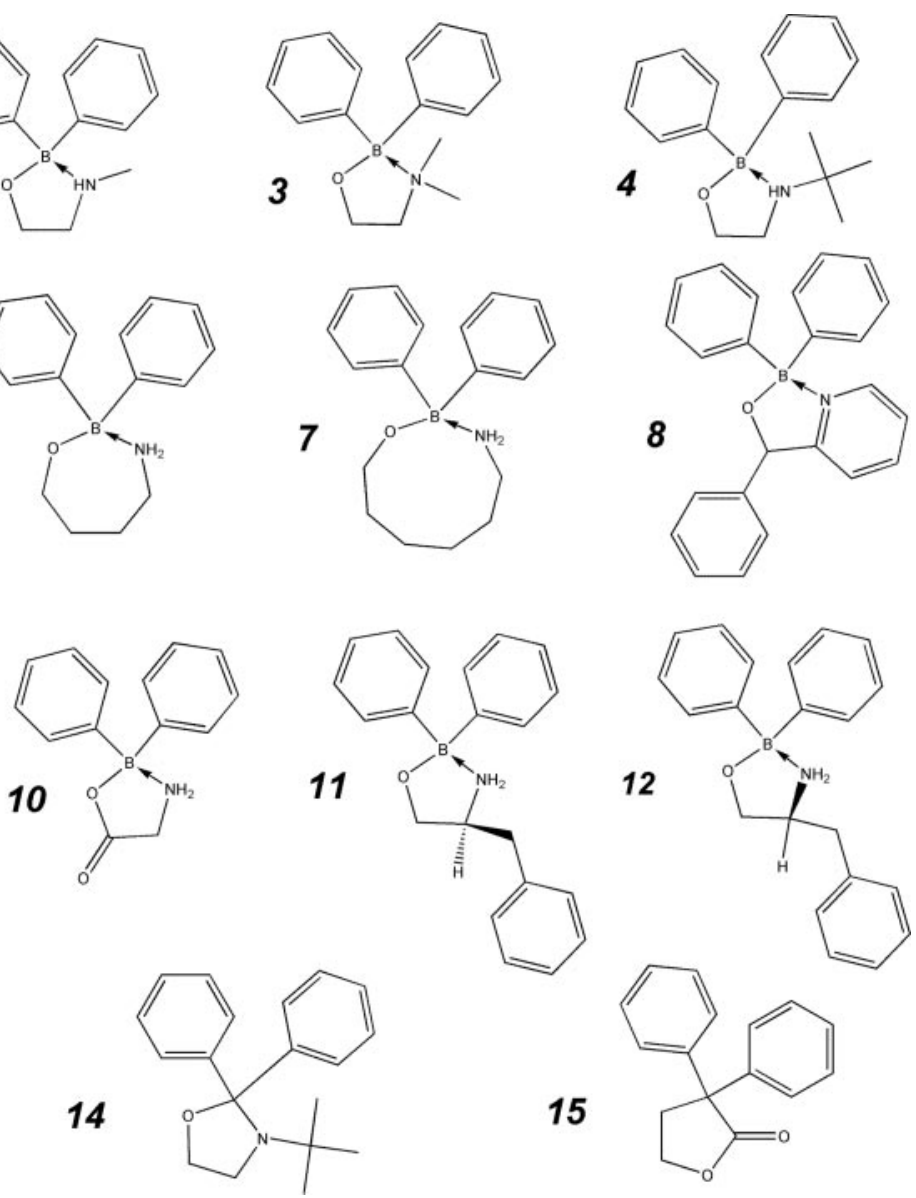

Fig. 3. Structures of compounds (1 through 14) synthesized in this study. The method for the synthesis of each compound is detailed in the text. Compound 15 (3,3-diphenyl dihydrofuran-2-one) was obtained from a commercial source (ACROS). Compounds $5,8,9,11$, and 12 contain a chiral carbon atom. Compounds 5, 8, and 9 are racemic mixtures. 
2,2-Diphenyl-1,3,2-oxazaborepane (6). 4-Amino-1-butanol $(0.053 \mathrm{~g})$ was added to $0.20 \mathrm{~g}$ of diphenylborinic anhydride in $8.0 \mathrm{ml}$ of acetonitrile. The product precipitated from solution to give $0.020 \mathrm{~g}$ of compound 6 (27\% yield); melting point, 185.60 to $186.1^{\circ} \mathrm{C} .{ }^{1} \mathrm{H}$ NMR (d $d_{6}$-DMSO): $\delta 1.58\left(\mathrm{p}, \mathrm{CH}_{2}\right), 1.67\left(\mathrm{p}, \mathrm{CH}_{2}\right), 2.71\left(\mathrm{p}, \mathrm{CH}_{2}\right), 3.59\left(\mathrm{t}, \mathrm{CH}_{2}\right)$, $5.82\left(\mathrm{t}, \mathrm{NH}_{2}\right), 7.01(\mathrm{t}, 2 \mathrm{H}), 7.12(\mathrm{t}, 4 \mathrm{H}), 7.45(\mathrm{dd}, 4 \mathrm{H})$. Analysis: calculations for $\mathrm{C}_{16} \mathrm{H}_{20} \mathrm{BNO}$ : C, 75.95; H, 7.98; N, 5.58; found: $\mathrm{C}$, 76.47; H, 8.04; N, 5.59.

2,2-Diphenyl-1,3,2-oxazaboronane (7). 6-Amino-1-hexanol $(0.073 \mathrm{~g})$ was added to $0.20 \mathrm{~g}$ of diphenylborinic anhydride in $8.0 \mathrm{ml}$ of acetonitrile. The product precipitated to give $0.228 \mathrm{~g}$ of compound 7 ( $32 \%$ yield); melting point, 70.0 to $71.0^{\circ} \mathrm{C} .{ }^{1} \mathrm{H}$ NMR $\left(d_{6}\right.$-DMSO): $\delta$ $1.28\left(\mathrm{p}, \mathrm{CH}_{2}\right), 1.35\left(\mathrm{p}, \mathrm{CH}_{2}\right), 1.42\left(\mathrm{p}, \mathrm{CH}_{2}\right), 1.63\left(\mathrm{p}, \mathrm{CH}_{2}\right), 2.63$ (q, $\mathrm{CH}_{2}$ ), 3.33 (broad s, $\mathrm{NH}_{2}$ ), $3.46\left(\mathrm{t}, \mathrm{CH}_{2}\right.$ ), 7.08 (t, 2H), 7.17 (t, $\left.4 \mathrm{H}\right), 7.53$ (dd, $4 \mathrm{H}$ ). Analysis: calculations for $\mathrm{C}_{18} \mathrm{H}_{24} \mathrm{BNO}$ : $\mathrm{C}, 72.73 ; \mathrm{H}, 8.26 ; \mathrm{N}$, 11.57; found: $\mathrm{C}, 72.33 ; \mathrm{H}, 8.08 ; \mathrm{N}, 11.04$. The peak at 3.33 rapidly exchanged with the addition of $\mathrm{D}_{2} \mathrm{O}$.

2,2,5-Triphenyl-benzo[3,4]-1,3,2-oxazaborolidine (8). Sodium borohydride $(0.107 \mathrm{~g})$ was added to $0.50 \mathrm{~g}$ of 2-acetylpyridine in 2.0 $\mathrm{ml}$ of methanol to yield $0.293 \mathrm{~g}$ of 2-(1-hydroxyethyl)pyridine after stirring for $30 \mathrm{~min}$. The precipitate was filtered out of the solution using vacuum filtration and dried. 2-(1-Hydroxyethyl) pyridine $(0.283 \mathrm{~g})$ was added to $0.825 \mathrm{~g}$ of diphenylborinic anhydride in 31.0 $\mathrm{ml}$ of acetonitrile. The product precipitated to yield $0.473 \mathrm{~g}$ of the compound 8 (yield $69.2 \%$ ); melting point, 200 to $201.1^{\circ} \mathrm{C}$ (literature melting point, $199-200^{\circ} \mathrm{C}$; Farfan et al., 1992).

5-Methyl-2,2-diphenyl-benzo[3,4]-1,3,2-oxazaborolidine (9). A $0.277-g$ sample of 2-(1-hydroxyethyl)pyridine was stirred with $0.518 \mathrm{~g}$ of diphenylborinic anhydride in $30.0 \mathrm{ml}$ of acetonitrile. The product precipitated to give $0.381 \mathrm{~g}$ of compound 9 (72.8\% yield); melting point, 164.2 to $164.9^{\circ} \mathrm{C}$ (literature melting point, $164-165^{\circ} \mathrm{C}$; Farfan et al., 1992).

2,2-Diphenyl-1,3,2-oxazaborolidine-5-one (10). Diphenylborinic anhydride $(0.2 \mathrm{~g})$, dissolved in $20.0 \mathrm{ml}$ of acetonitrile, was stirred at with $0.058 \mathrm{~g}$ of the sodium salt of glycine. The acetonitrile was removed under nitrogen to give $0.238 \mathrm{~g}$ of compound $10(45 \%$ yield); melting point, 235 to $238^{\circ} \mathrm{C} .{ }^{1} \mathrm{H}$ NMR ( $d_{6}$-DMSO): 3.47 (t, $\mathrm{CH}_{2}$ ), $7.09\left(\mathrm{t}, \mathrm{NH}_{2}\right), 7.17(\mathrm{~m}, 2 \mathrm{H}), 7.23(\mathrm{~m}, 4 \mathrm{H}), 7.39(\mathrm{~m}, 4 \mathrm{H})$. Analysis: calculations for $\mathrm{C}_{14} \mathrm{H}_{14} \mathrm{BNO}_{2}: 70.43 ; \mathrm{H}, 5.80 ; \mathrm{N}, 5.86$; found: $\mathrm{C}$, $70.12 ; \mathrm{H}, 5.83 ; \mathrm{N}, 5.80$. The triplet at 7.09 rapidly exchanged with the addition of $\mathrm{D}_{2} \mathrm{O}$.

(S)-4-Benzyl-2,2-diphenyl-1,3,2-oxazaborolidine (11). $(S)(-)$ 2-Amino-3-phenyl-1-propanol (0.50 g) was dissolved in $11.0 \mathrm{ml}$ of acetonitrile and treated with a solution of $1.14 \mathrm{~g}$ of diphenylborinic anhydride in $9.0 \mathrm{ml}$ of acetonitrile. The reaction was stirred for 1 week, and then the solvent was removed with nitrogen gas to give $0.556 \mathrm{~g}$ of compound 11 (60\% yield); melting point, 129 to $135^{\circ} \mathrm{C} .{ }^{1} \mathrm{H}$ NMR ( $d_{6}$-DMSO): $2.734(\mathrm{dd}, 1 \mathrm{H}), 2.94(\mathrm{dd}, 1 \mathrm{H}), 3.35(\mathrm{~m}, 1 \mathrm{H}), 3.55(\mathrm{t}$, $1 \mathrm{H}), 3.81(\mathrm{t}, 1 \mathrm{H}), 5.80(\mathrm{t}, 1 \mathrm{H}), 6.42(\mathrm{t}, 1 \mathrm{H}), 7.05$ to $7.45(\mathrm{~mm}, 15 \mathrm{H})$. Analysis: calculations for $\mathrm{C}_{21} \mathrm{H}_{22} \mathrm{BNO}$ : $\mathrm{C}, 80.0 ; \mathrm{H}, 6.98 ; \mathrm{N}, 4.45$; found: $\mathrm{C}, 79.89 ; \mathrm{H}, 6.95 ; \mathrm{N}, 4.54$. The two triplets at 5.80 and 6.42 are assigned to the two nonequivalent $\mathrm{NH}$ protons rapidly exchanged with the addition of $\mathrm{D}_{2} \mathrm{O}$.

(R)-4-Benzyl-2,2-diphenyl-1,3,2-oxazaborolidine (12). $(R)(+)$ 2-Amino-3-phenyl-1-propanol (0.50 g) was dissolved in $30.0 \mathrm{ml}$ of acetonitrile and treated with a solution of $1.14 \mathrm{~g}$ of diphenylborinic anhydride in $9.0 \mathrm{ml}$ of acetonitrile. The solution was stirred at for 4 days when the solvent was removed with nitrogen gas to give 0.510 $\mathrm{g}$ of compound 12 (55\% yield); melting point, 120 to $125^{\circ} \mathrm{C} .{ }^{1} \mathrm{H}$ NMR (d $d_{6}$-DMSO): $2.73(\mathrm{dd}, 1 \mathrm{H}), 2.94(\mathrm{dd}, 1 \mathrm{H}), 3.35(\mathrm{t}, 1 \mathrm{H}), 3.81(\mathrm{t}, 1 \mathrm{H})$, $5.80(\mathrm{t}, 1 \mathrm{H}), 6.42(\mathrm{t}, 1 \mathrm{H}), 7.05$ to $7.45(\mathrm{~mm}, 15 \mathrm{H})$. Analysis: calculations for $\mathrm{C}_{21} \mathrm{H}_{22}$ BNO: C, 80.0; $\mathrm{H}, 6.98 ; \mathrm{N}, 4.45$; found: $\mathrm{C}, 79.66 ; \mathrm{H}$, 7.18; N, 5.25. The two triplets at 5.80 and 6.42 are assigned to the two nonequivalent $\mathrm{NH}$ protons rapidly exchanged with the addition of $\mathrm{D}_{2} \mathrm{O}$.

Synthesis of Oxazolidine Analogs. Dichlorodiphenylmethane was prepared from benzophenone and phosphorus pentachloride according to the method of Staudinger and Freudenberger (1943).

3-Methyl-2,2-diphenyl-1,3-oxazolidine (13). Silver oxide (2.0 g, $8.6 \mathrm{mmol})$ was added to a mixture of dichlorodiphenylmethane $(2.0 \mathrm{~g}$, $9.4 \mathrm{mmol}$ ) and 2-(methylamino)ethanol (1.4 ml, $17 \mathrm{mmol}$ ). The mixture was warmed on a hot plate until a violent reaction ensued (Scheme 1). The mixture was cooled, and the solid residue was washed repeatedly with hexanes. The combined filtrates were washed with water, dried over sodium sulfate, filtered, and concentrated in vacuo. The residue was distilled under high vacuum. The distillate was recrystallized from hexanes giving $0.87 \mathrm{~g}$ of compound 13 (3.6 mmol, $42 \%$ yield). NMR spectra were in agreement with published data (Azzena et al., 1993).

3-tert-Butyl-2,2-diphenyl-1,3-oxazolidine (14). Silver acetate (1.7 g, $10.2 \mathrm{mmol}$ ) was added to a mixture of dichlorodiphenylmethane $(1.0 \mathrm{~g}, 4.7 \mathrm{mmol})$ and 2-(tert-butylamino)ethanol (5.5 g, 47 mmol). The mixture was warmed on a hotplate for 30 min during which a brown solid appeared (Scheme 2). The reaction was allowed to cool, and the solid was washed with hexanes (100 ml). The hexane filtrate was washed three times with water (100 ml each), dried over sodium sulfate, and concentrated in vacuo. Crystals formed slowly upon standing, which were placed on an absorbant tissue to remove the benzophenone side-product that remains in the melt. The product 14 thus obtained was $230 \mathrm{mg}(0.82 \mathrm{mmol}, 17 \%$ yield $)$ with a melting point of 66 to $68^{\circ} \mathrm{C} .{ }^{1} \mathrm{H} \mathrm{NMR}\left(\mathrm{CDCl}_{3}\right)$ : $\delta 7.59(\mathrm{~m}, 4 \mathrm{H}), 7.27(\mathrm{~m}$, $6 \mathrm{H}), 3.76(\mathrm{t}, J=6.5 \mathrm{~Hz}, 2 \mathrm{H}), 3.31(\mathrm{t}, J=6.5 \mathrm{~Hz}, 2 \mathrm{H}), 0.92(\mathrm{~s}, 9 \mathrm{H}) ;{ }^{13} \mathrm{C}$ $\mathrm{NMR}\left(\mathrm{CDCl}_{3}\right): \delta 144.5,129.6,127.5,127.3,99.7,63.0,54.5,47.6$, 29.9. The compound was sublimed under vacuum for analysis. Analysis: calculations for $\mathrm{C}_{19} \mathrm{H}_{23} \mathrm{NO}: \mathrm{C}, 81.10 ; \mathrm{H}, 8.24 ; \mathrm{N}, 4.98$; found: $\mathrm{C}$, $80.98 ; \mathrm{H}, 8.33$; N, 4.81 .

2,2-Diphenyl-1,3-oxazolidine (16). We were unable to isolate 2 , 2-diphenyl-1,3-oxazolidine (compound 16), which is the carbon ana$\log$ of the ring form of 2-APB, where the boron is replaced by a carbon. Results from the parent oxazolidine are therefore not reported. The compound, however, was successfully prepared by the condensation of ethanol amine with benzophenone imine. Nevertheless, the oxazolidine 16 exists as an equilibrium mixture with its ring-opened 17 tautomer (Fig. 4). Proton NMR analysis suggests a ratio of 14:86 in favor of the ring-opened form. The evidence for the ring-opened structure is the nonequivalence of the phenyl rings. The phenyl rings in the ring-open tautomer are diastereomeric because the imine double bond. The ${ }^{1} \mathrm{H}$ NMR shows four sets of strong aromatic resonances at $7.62,7.46,7.34$, and $7.17 \mathrm{ppm}$. The ringclosed structure should show only two strong signals for the sets of
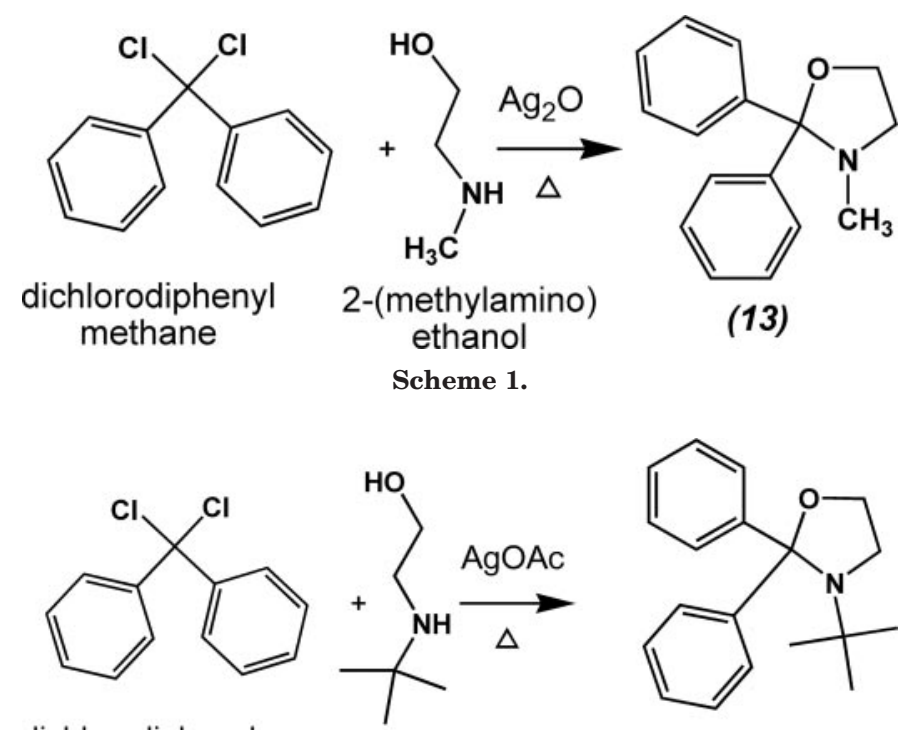

dichlorodiphenyl methane

\section{2-(tert-butylamino) ethanol}

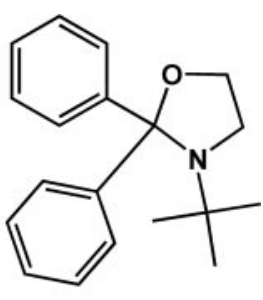

(14)
Scheme 2. 
four equivalent ortho and meta hydrogens, respectively. In the alipahtic region, there are two pairs of triplets. The major pair occurs at 3.84 and $3.48 \mathrm{ppm}$, whereas the minor pair occurs at 3.85 (obscured by the major isomer) and $3.15 \mathrm{ppm}$. The methylenes adjacent to the nitrogen are the upfield resonances of each set. The imine structure of the ring-opened isomer gives rise to the shift from 3.15 to 3.48 ppm. Finally, the chemical shifts of the aliphatic protons of the ring-closed methyl derivative 13 are similar to those of the minor isomer. Precedent for ring-opening tautomerization has been reported. Thus, the oxazoline from acetophenone and ethanolamine exists as a 50:50 mixture with the ring-opened form (Konkova et al., 1999). It is reasonable to suggest that the conjugation provided by the extra phenyl ring in benzophenone results in a greater proportion of the imine form.

Blood Donors and Platelet Preparation. All donors were healthy nonsmoking volunteers (age 20-60 years) who had not consumed any medication known to affect platelet function (e.g., calcium-channel blockers and aspirin) for at least 10 days before the study. Venous blood was collected into $1 / 10$ volume of $(74.8 \mathrm{mM}$ sodium citrate, $38.1 \mathrm{mM}$ citric acid, and $123 \mathrm{mM}$ dextrose, $\mathrm{pH}$ 6.4) (Baxter, McGaw Park, IL). The blood was centrifuged at $250 \mathrm{~g}$ for 10 min at room temperature to obtain platelet-rich plasma. The platelet-rich plasma was centrifuged at $550 \mathrm{~g}$ for $12 \mathrm{~min}$ to sediment the platelets. The platelets were then resuspended in a modified Tyrode's physiological salt solution $(145 \mathrm{mM} \mathrm{NaCl}, 4 \mathrm{mM} \mathrm{KCl}, 1 \mathrm{mM}$ $\mathrm{MgSO}_{4}, 0.5 \mathrm{mM} \mathrm{Na} \mathrm{HPO}_{4}, 10 \mathrm{mM}$ sodium-HEPES and $6 \mathrm{mM}$ glucose, $\mathrm{pH}$ 7.4) containing $1.0 \mathrm{mM}$ EGTA to prevent spontaneous aggregation during the various experimental manipulations by binding extracellular $\mathrm{Ca}^{2+}$.

Platelet Loading with Fura-2 and Measurement of $\left[\mathrm{Ca}^{2+}\right]_{i}$. Intracellular calcium measurements $\left[\mathrm{Ca}^{2+}\right]_{\mathrm{i}}$ used the fluorescent dye Fura-2, which involved incubating the platelets with the cell-permeant acetoxymethyl ester (Fura-2/AM). Suspensions of human platelets (isolated as described above) were incubated with $2 \mu \mathrm{M}$ Fura-2/AM for $1 \mathrm{~h}$ at room temperature (on a rocking platform). Excess Fura-2/AM was removed by centrifugation (500 $\mathrm{g}$ for $10 \mathrm{~min}$ ), and the platelets were suspended in modified Tyrode's buffer without added EGTA. Aliquots of platelet suspension $(0.5 \mathrm{ml})$ were added to 1-ml cuvettes containing a Teflon-coated stirrer bar (CHRONO-LOG, Havertown, PA). To measure intracellular $\mathrm{Ca}^{2+}$ mobilization, $\mathrm{Ca}^{2+}$ was not added to the platelet suspension; test compounds were added at approximately $10 \mathrm{~s}$, then at $20 \mathrm{~s}, 0.01 \mathrm{units} / \mathrm{ml}$ thrombin was added. To evaluate $\mathrm{Ca}^{2+}$ influx, approximately $30 \mathrm{~s}$ before $\left[\mathrm{Ca}^{2+}\right]_{\mathrm{i}}$ measurements were performed, $\mathrm{Ca}^{2+}$ was added back to the buffer to
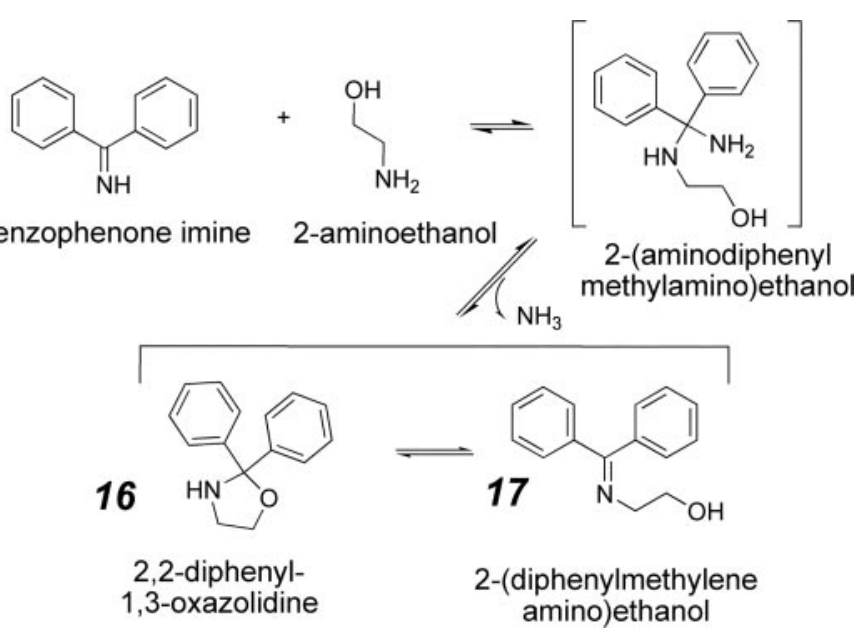

Fig. 4. Structures of the proposed tautomeric forms of the nonboron analog of 2-APB, 2,2-diphenyl-1,3-oxazolidine (16), and 2-(diphenylmethyleneamino)ethanol (17). The formation of compounds 16 and 17 involved condensing ethanol amine with benzophenone imine after deamination of the 2-(aminodiphenylmethylamino)ethanol intermediate. a final concentration of $2.0 \mathrm{mM}$, and then test compounds were dissolved in $\mathrm{Me}_{2} \mathrm{SO}$ (various concentrations in $2.5 \mu \mathrm{l}$ ), and thrombin 0.01 units $/ \mathrm{ml}$ were added. The measurements of $\left[\mathrm{Ca}^{2+}\right]_{\mathrm{i}}$ was performed at room temperature in a SPEX ARCM spectrofluorometer (SPEX Industries, Edison, NJ) using excitation wavelengths of 340 and $380 \mathrm{~nm}$ and an emission wavelength of $505 \mathrm{~nm}$. Calibration was performed as described previously (Dobrydneva and Blackmore, 2001). $\left[\mathrm{Ca}^{2+}\right]_{\mathrm{i}}$ was calculated by using the SPEX dM3000 software. The data in Fig. 5 show a typical experiment. To calculate the percentage of inhibition of thrombin effects by the various analogs, the $\left[\mathrm{Ca}^{2+}\right]_{\mathrm{i}}$ before thrombin addition was measured; then, the $\left[\mathrm{Ca}^{2+}\right]_{\mathrm{i}}$ was measured after the thrombin effect had reached a maximum value (which was approximately after $1 \mathrm{~min}$ ). The difference was then compared with the effect observed in the absence of any inhibitor (control), which represents $0 \%$ inhibition.

\section{Results and Discussion}

Chemistry. All of the 2-APB analogs that we synthesized were obtained in 27 to $76 \%$ yields after purification by recrystallization. The reactions were temperature-dependent, leading to high yields at cool temperatures and low yields at warm temperatures. It is believed that the low yields at warm temperatures could be caused by the acetonitrile reacting with the diphenylboronic anhydride before the amine could be added. A possible product may be the acetonitrile adduct of diphenylboronic anhydride, formed when the unpaired electrons of acetonitrile forms an $\mathrm{N} \rightarrow \mathrm{B}$ coordinate bond (Fig. 6). This finding illustrates one possible pitfall when synthesizing boron-containing compounds in the presence of solvents (e.g., acetonitrile) or reactants with unpaired electrons that could form coordinate bonds. At warm temperatures, the solution of acetonitrile and anhydride developed a golden color, whereas at cooler temperatures, the solution remains colorless, which suggests some involvement of the solvent acetonitrile. To avoid the contamination of the product produced when acetonitrile and diphenylboronic anhydride react, the reaction vessel was placed in an ice bath for the duration of the reaction, and the recrystallizing solvents

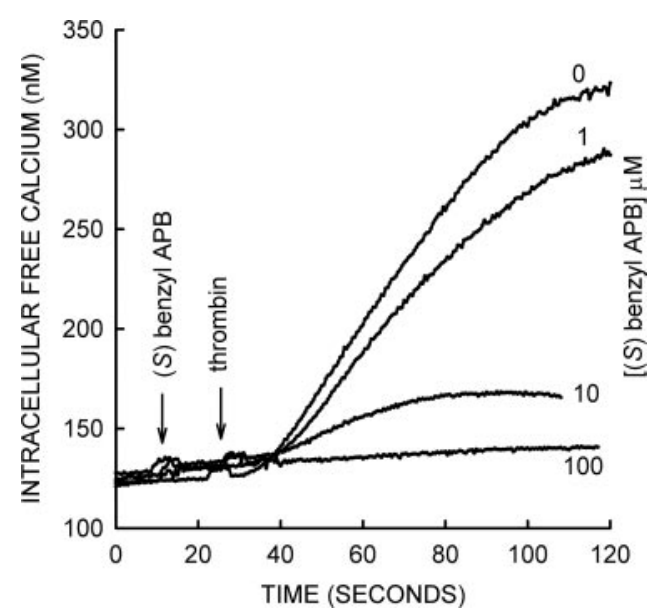

Fig. 5. The effect of ( $S$ )-4-benzyl-2,2-diphenyl-1,3,2-oxazaborolidine (11) on the ability of thrombin to increase $\left[\mathrm{Ca}^{2+}\right]_{\mathrm{i}}$ in the presence of extracellular calcium. Extracellular calcium $2.0 \mathrm{mM}$ was added to the platelet suspension $30 \mathrm{~s}$ before data collection was started. Approximately $10 \mathrm{~s}$ after data collection was commenced, various concentrations (1, 10, and $100 \mu \mathrm{M}$ ) of (S)-4-benzyl-2,2-diphenyl-1,3,2-oxazaborolidine (11) were added to the platelet suspension. Thrombin $(0.01$ units $/ \mathrm{ml})$ was added approximately $10 \mathrm{~s}$ later. A representative experiment is shown, The ability of thrombin to increase $\left[\mathrm{Ca}^{2+}\right]_{\mathrm{i}}$ was inhibited in a dose-dependent fashion by ( $S$ )-4-benzyl-2,2-diphenyl-1,3,2-oxazaborolidine (11). 
were changed to ethyl acetate and benzene. All of these 2-APB analogs were in agreement with the carbon, hydrogen, and nitrogen analyses and exhibited the predicted functional group absorptions in the infrared. The NMR findings of these compounds were in good agreement with the assigned structures.

One of the intriguing aspects of the structural analysis of 2-APB was observed in the NMR data for this series of compounds. 2-APB can be visualized as either an open-chain form or a ring structure (Fig. 1) because of the potential coordinate covalent bond that might arise between the electron-rich amine and the electron-deficient boron. The existence of the ring form is indeed confirmed by the crystal structure of 2-APB (Retting and Trotter, 1976) which shows a heterocyclic form in staggered arrays, with each molecule linked to two others through hydrogen bonds. An examination of the NMR of 2-APB in $d_{6}$-DMSO shows that the $\mathrm{NH}_{2}$ protons are indeed in a highly deshielded position (6-7 ppm), which is also suggestive of a ring rather than of an openchain structure. In contrast, the $\mathrm{NH}_{2}$ peak for ethanolamine is found at $3.3 \mathrm{ppm}$. This series of 2 -APB analogs was designed to examine this ring concept for 2 -APB and also to determine whether a five-membered ring was needed or whether larger rings would be active (compounds 6 and 7). The objective was to determine whether chain extension could resolve the question of the coordination of the $\mathrm{NH}_{2}$ group to boron. The $N$-methyl (compounds 2 and 3), and $N$-butyl (4) analogs, as well as the phenyl (5) and butyl (6) analogs, all showed the $\mathrm{NH}$ and $\mathrm{NH}_{2}$ protons to be highly deshielded in the 5.9- to 6.8-ppm region in $d_{6}$-DMSO. This would suggest that these analogs were also in a similar ring structure because of the proximity of the $\mathrm{NH}$ and $\mathrm{NH}_{2}$ groups to the electron-deficient boron. However, NMR data for the hexyl analog (compound 7) in $d_{6}$-DMSO showed the $\mathrm{NH}_{2}$ protons to be at $3.3 \mathrm{ppm}$, which is in keeping with an openchain structure. Thus, extending the length of the ethanol-
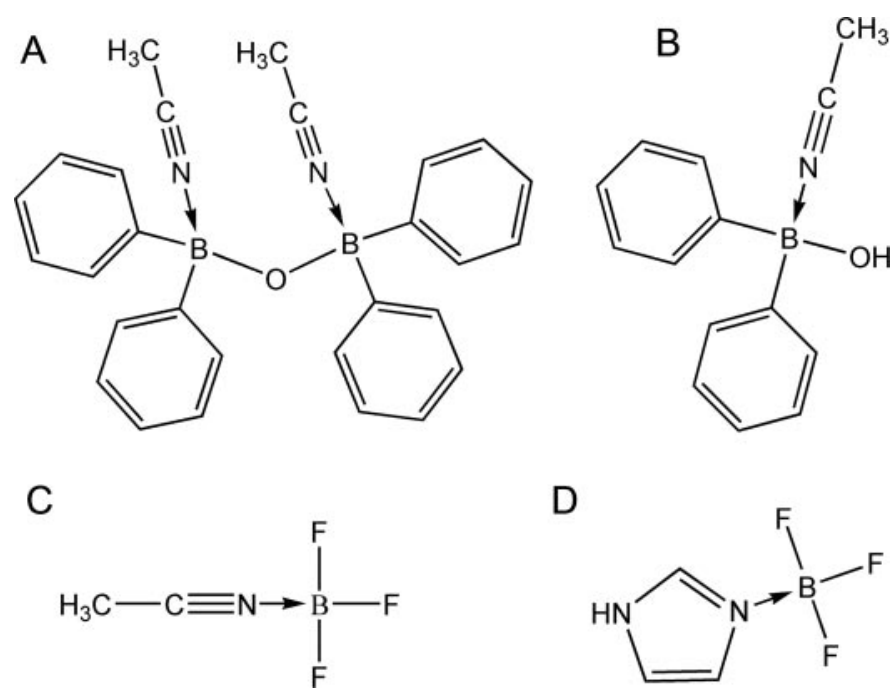

Fig. 6. Proposed structure of the acetonitrile adducts of diphenylborinic acid anhydride. Product $\mathrm{A}$ is a diacetonitrile adduct of diphenylborinic anhydride, and product $\mathrm{B}$ is a monoacetonitrile adduct of diphenylborinic acid that could result from the hydrolysis of adduct $\mathrm{A}$. The structure shown in $\mathrm{C}$ is the result of combining acetonitrile with boron trifluoride, and this adduct is commercially available (Sigma-Aldrich), whereas adduct $\mathrm{D}$ (which has been crystalized) is the result of reaction between imidazole with boron trifluoride. amine side chain in 2-APB by adding two extra carbons (ethyl to butyl) did not prevent ring formation on the basis of the NMR data. However, extending the length of the side chain by another two carbons (butyl to hexyl) prevented the formation of a ring, on the basis of the NMR data. The reason for this is not clear; however, the longer side chain decreases the probability that the nitrogen's unpaired electrons will be in close proximity to the boron and hence lessen the likelihood that a coordinate bond will be formed. The formation of hexyl dimers would also be less likely to occur because either one or two coordinate bonds would have to be formed. As seen in Table 1, hexyl-APB (compound 7), butyl-APB (6), and 2-APB (1) all have the same ability to inhibit thrombin, despite hexyl-2-APB (7) not forming a ring. However, we should caution extrapolating NMR data performed in dimethylsulfoxide and biological data in which cells are incubated in an aqueous buffered salt solution at $\mathrm{pH}$ 7.4. Under these aqueous conditions, we do not know the proportion of open-chain, ring, and dimer forms of 2-APB and its analogs.

The presence of a chiral center gives rise to the interesting splitting pattern of the adjacent protons. A distinctive structural feature of the two stereoisomers (compounds 11 and 12) produced in this study was observed in their NMR spectra. As might be expected, the two $R$ - and $S$-enantiomers would necessarily have the same basic NMR patterns, and indeed, this is observed in $d_{6}$-DMSO. The NMR data further suggest that the two $\mathrm{NH}_{2}$ protons in the $R$ - and $S$-compounds are essentially nonequivalent. This nonequivalence produces a triplet arising from the mutual splitting of the two $\mathrm{NH}_{2}$ protons and subsequent splitting by the adjacent proton on the optically active center. The protons adjacent to the oxygen in these two compounds are also apparently nonequivalent as well and are split into a set of triplets. The protons at the chiral center of this oxazaborolidine ring system are also nonequivalent and are therefore split into a set of doublets of doublets.

TABLE 1

The effect of 2-APB derivatives and nonboron-containing analogs on thrombin-induced increases in $\left[\mathrm{Ca}^{2+}\right]_{\mathrm{i}}$ in the presence of extracellular calcium in platelets (predominantly calcium influx)

Abbreviated trivial names are shown for simplicity, together with a designated number for each compound (Fig. 3).

\begin{tabular}{lccc}
\hline \multirow{2}{*}{$\begin{array}{c}\text { Compound Name } \\
\text { (Number) }\end{array}$} & \multicolumn{3}{c}{$\begin{array}{c}\text { Inhibition of Thrombin Response } \\
\text { at Compound Concentration }\end{array}$} \\
\cline { 2 - 4 } & $100 \mu \mathrm{M}$ & $10 \mu \mathrm{M}$ & $1 \mu \mathrm{M}$ \\
\hline & $98 \pm 6$ & $47 \pm 8$ & $16 \pm 4$ \\
2-APB (1) & $96 \pm 1$ & $31 \pm 10$ & $7 \pm 5$ \\
Monomethyl APB (2) & $99 \pm 1$ & $45 \pm 6$ & $15 \pm 8$ \\
Dimethyl APB (3) & $98 \pm 1$ & $43 \pm 7$ & $11 \pm 4$ \\
$t$-Butyl APB (4) & $96 \pm 1$ & $52 \pm 6$ & $10 \pm 2$ \\
Phenyl APB (5) & $97 \pm 3$ & $48 \pm 9$ & $8 \pm 5$ \\
Butyl APB (6) & $98 \pm 0$ & $39 \pm 9$ & $15 \pm 3$ \\
Hexyl APB (7) & $-{ }^{a}$ & $74 \pm 3$ & $14 \pm 7$ \\
Phenyl pyridyl APB (8) & $98 \pm 1$ & $55 \pm 10$ & $3 \pm 12$ \\
Methyl pyridyl APB (9) & $16 \pm 1$ & $-2 \pm 3$ & $\mathrm{~N} . \mathrm{D}$. \\
Glycine ester APB (10) & $97 \pm 5$ & $86 \pm 8$ & $34 \pm 11$ \\
(R)-Benzyl APB (11) & $91 \pm 6$ & $82 \pm 7$ & $48 \pm 5$ \\
(S)-Benzyl APB (12) & $53 \pm 7$ & $37 \pm 9$ & $15 \pm 13$ \\
Methyloxazolidine (13) & $83 \pm 5$ & $55 \pm 5$ & $19 \pm 10$ \\
$t$-Butoxazolidine (14) & $59 \pm 4$ & $17 \pm 8$ & $-7 \pm 9$ \\
Diphenylbutyrolactone (15) & $69 \pm 9$ & $62 \pm 6$ & $36 \pm 8$ \\
Diphenyltetrahydrofuran ${ }^{b}$ & $69 \pm 9$ & \\
\hline
\end{tabular}

N.D., not determined.

${ }^{a}$ Stimulates calcium influx by itself at $100 \mu \mathrm{M}$.

${ }^{b}$ From Dobrydneva and Blackmore (2001). 
The rationale for the synthesis of the 2,2-diphenyl-1,3,2oxazaborolidine-5-one (compound 10) from the condensation of diphenylborinic anhydride and the sodium salt of glycine was taken from the possibility that greater activity might be achieved by creating a better leaving group within the 2 -APB structure. This would assume that the activity of this class of compounds may be related to an interaction of some nucleophilic moiety on the receptor/channel protein with the highly polarized 2-APB ring system. This might lead to the subsequent displacement of the coordinately bound $\mathrm{NH}_{2}$ group from the 2-APB moiety and provide for a reversible attachment to the receptor/channel site. By introducing the ester moiety into the basic 2-APB structure, this type of interaction was expected to be enhanced and may produce a more effective interaction with the SOCE receptor protein. However, this compound was a very weak inhibitor of thrombininduced $\mathrm{Ca}^{2+}$ influx at $100 \mu \mathrm{M}$ (see below).

2-APB Derivatives Block Thrombin-Induced $\mathrm{Ca}^{2+}$ Elevation. In the present study, we examined the capacity of the various analogs to inhibit the ability of thrombin to increase $\left[\mathrm{Ca}^{2+}\right]_{\mathrm{i}}$ in platelets in the presence of extracellular calcium (Table 1) and in the absence of extracellular calcium (Table 2). When extracellular calcium was present, approximately 80 to $90 \%$ of the increase in $\left[\mathrm{Ca}^{2+}\right]_{\mathrm{i}}$ induced by low concentrations of thrombin $(0.01 \mathrm{units} / \mathrm{ml})$ was caused by calcium influx (Dobrydneva and Blackmore, 2001). This was because in the absence of extracellular calcium, the increase in $\left[\mathrm{Ca}^{2+}\right]_{\mathrm{i}}$ induced by thrombin was approximately 10 to $20 \%$ of that observed when extracellular calcium was present.

Modification of the oxazaborolidine ring in the 2-APB analogs does not alter activity substantially, except for the glycyl ester (compound 10), which had a small 16\% inhibitory activity at $100 \mu \mathrm{M}$ and no activity at lower concentrations (Table 1). Most of the 2-APB (compound 1) analogs that we synthesized possessed approximately the same ability to inhibit thrombin-induced $\left[\mathrm{Ca}^{2+}\right]_{\mathrm{i}}$ increase (Table 1 ). This in-

\section{TABLE 2}

The effect of 2-APB derivatives and nonboron-containing analogs on thrombin-induced increases in $\left[\mathrm{Ca}^{2+}\right]_{\mathrm{i}}$ in the absence of extracellular calcium in platelets (internal calcium mobilization)

Abbreviated trivial names are shown for simplicity together with a designated number for each compound (Fig. 3).

\begin{tabular}{lrrr}
\hline \multirow{2}{*}{$\begin{array}{c}\text { Compound Name } \\
\text { (Number) }\end{array}$} & \multicolumn{3}{c}{$\begin{array}{c}\text { Inhibition of Thrombin Response } \\
\text { at Compound Concentration }\end{array}$} \\
\cline { 2 - 4 } & $100 \mu \mathrm{M}$ & $10 \mu \mathrm{M}$ & $1 \mu \mathrm{M}$ \\
\hline & $91 \pm 2$ & $54 \pm 9$ & $36 \pm 5$ \\
2-APB (1) & $90 \pm 2$ & $16 \pm 1$ & $3 \pm 3$ \\
Monomethyl APB (2) & $86 \pm 6$ & $16 \pm 2$ & $0 \pm 4$ \\
Dimethyl APB (3) & $89 \pm 2$ & $5 \pm 3$ & $4 \pm 8$ \\
$t$-Butyl APB (4) & $96 \pm 2$ & $25 \pm 4$ & $5 \pm 4$ \\
Phenyl APB (5) & $91 \pm 4$ & $20 \pm 1$ & $6 \pm 3$ \\
Butyl APB (6) & $90 \pm 3$ & $23 \pm 4$ & $8 \pm 8$ \\
Hexyl APB (7) & $88 \pm 6$ & $24 \pm 5$ & $10 \pm 8$ \\
Phenyl pyridyl APB (8) & $-{ }^{a}$ & $16 \pm 4$ & $0 \pm 5$ \\
Methyl pyridyl APB (9) & $29 \pm 16$ & $0 \pm 5$ & $\mathrm{~N} . \mathrm{D}$. \\
Glycine ester APB (10) & $100 \pm 1$ & $49 \pm 9$ & $12 \pm 7$ \\
(R)-Benzyl APB (11) & $95 \pm 6$ & $59 \pm 11$ & $13 \pm 6$ \\
(S)-Benzyl APB (12) & $24 \pm 9$ & $14 \pm 9$ & $0 \pm 4$ \\
Methyloxazolidine (13) & $94 \pm 6$ & $37 \pm 2$ & $16 \pm 6$ \\
$t$-Butoxazolidine (14) & $13 \pm 7$ & $0 \pm 3$ & $\mathrm{~N} . \mathrm{D}$. \\
Diphenylbutyrolactone (15) & $51 \pm 7$ & $33 \pm 7$ & $30 \pm 11$ \\
Diphenyltetrahydrofuran ${ }^{b}$ & & & \\
\hline
\end{tabular}

\footnotetext{
N.D., not determined.

${ }^{a}$ Stimulates calcium release by itself at $100 \mu \mathrm{M}$.
}

${ }^{b}$ From Dobrydneva and Blackmore (2001). cluded phenyl-APB (5), dimethyl-APB (3), monomethyl-APB (2), $t$-butyl-APB (4), butyl-APB (6), hexyl-APB (7), and methyl-pyridyl APB (9). Dose responses are shown for 2-APB and butyl-APB in Fig. 7. Each of these compounds produced between 96 and $99 \%$ inhibition at $100 \mu \mathrm{M}$, between 31 and $74 \%$ inhibition at $10 \mu \mathrm{M}$, and between 3 and $16 \%$ inhibition at 1 $\mu \mathrm{M}$. Phenyl-pyridyl APB (8) stimulated $\mathrm{Ca}^{2+}$ influx at 100 $\mu \mathrm{M}$ by itself; however, at 10 and $1 \mu \mathrm{M}$, it was inhibitory. The response of $100 \mu \mathrm{M}$ phenyl pyridyl APB to increase $\left[\mathrm{Ca}^{2+}\right]_{\mathrm{i}}$ was approximately $50 \%$ of the increase observed with 0.01 units/ml thrombin (Fig. 7). The kinetics of the increase in $\left[\mathrm{Ca}^{2+}\right]_{\mathrm{i}}$ was similar to that observed with thrombin and much faster than that seen initially with the sarcoplasmic/endoplasmic reticulum calcium ATPase (SERCA) inhibitor thapsigargin. Thapsigargin initially produces a very small and slow increase in $\left[\mathrm{Ca}^{2+}\right]_{\mathrm{i}}$, (also Fig. 4 in Dobrydneva and Blackmore, 2001), then after approximately $1 \mathrm{~min}$, there is a rapid and large increase in $\left[\mathrm{Ca}^{2+}\right]_{i}$, probably caused by the generation of thromboxane, because the response was largely blocked by treating the platelets with aspirin (data not shown). Thus, we do not believe that phenyl pyridyl APB was increasing $\left[\mathrm{Ca}^{2+}\right]_{\mathrm{i}}$ by a mechanism involving the inhibition of SERCA because the kinetics and magnitude of increase in $\left[\mathrm{Ca}^{2+}\right]_{\mathrm{i}}$ are completely different from that seen with the SERCA inhibitor thapsigargin. We have not examined this phenomenon any further. There were two analogs that showed a greater potency than 2-APB to inhibit thrombin: these were $(R)$ - and (S)-benzyl-APB (compounds 11 and 12 ) (Fig. 8).

Previous studies in platelets showed that 2-APB inhibited calcium influx channels (Diver et al., 2001; Dobrydneva and Blackmore, 2001). 2-APB also inhibited calcium mobilization in platelets (Maruyama et al., 1997; Diver et al., 2001; Dobrydneva and Blackmore, 2001). We therefore also examined the effects of the 2-APB analogs on thrombin-induced calcium mobilization (Table 2 ) to determine whether they were

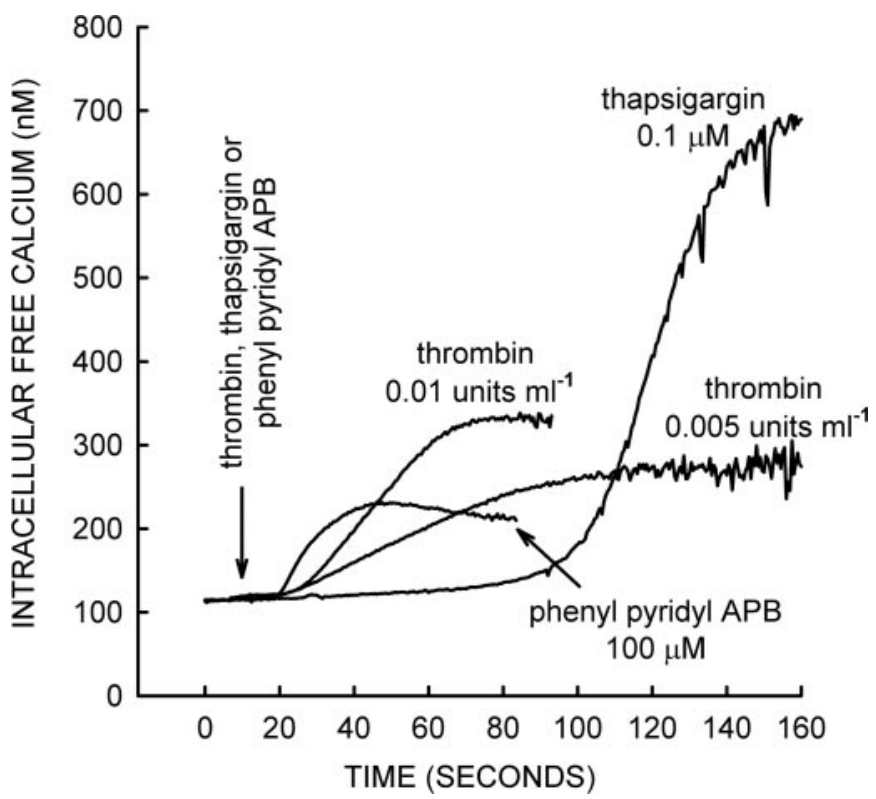

Fig. 7. Effect of phenyl pyridyl APB (8), thrombin, and thapsigargin to increase $\left[\mathrm{Ca}^{2+}\right]_{\mathrm{i}}$ in platelets in the presence of extracellular calcium. The concentration of phenyl pyridyl APB (8) was $100 \mu \mathrm{M}$, thapsigargin was $100 \mathrm{nM}$, and two concentrations of thrombin $(0.005$ and 0.01 units $/ \mathrm{ml})$ were used. Representative traces are shown. 
more selective at inhibiting either process. When one compares the inhibitory effects of each compound at a $10 \mu \mathrm{M}$ concentration, 2-APB was the most effective compound at inhibiting internal release with the exception of $(S)$-benzyl APB (compound 12), whereas at a $1 \mu \mathrm{M}$ concentration, 2-APB was clearly the most effective inhibitor, with a $36 \%$ inhibition (Table 2). When extracellular calcium was present and the inhibitory effects of each compound at a $10 \mu \mathrm{M}$ concentration were compared (Table 1), 2-APB possessed an inhibitory activity that was similar to that of many of the compounds (e.g., compounds 3, 4, and 6); however, several analogs were clearly more effective (e.g., compounds 8, 9, 11, 12, and 14). Several of the analogs were also more effective at the $1 \mu \mathrm{M}$ concentration (e.g., compounds 11, 12, and 14). Thus, many of the analogs synthesized had smaller inhibitory effects on internal release (Table 2) compared with 2-APB, whereas several analogs were more effective at inhibiting calcium influx (e.g., compounds 11 and 12). Despite extensive modifications to 2-APB, many of the compounds are able block both calcium influx and internal release, at least in platelets.

From this limited number of analogs examined, we propose a common pharmacophore that is responsible for inhibiting thrombin-induced calcium influx. This pharmacophore consists of two phenyl groups linked to either tetrahedral carbon or boron. This is confirmed by the fact that replacing the boron with a carbon such as in compounds 13 and 14 resulted in inhibitory activity comparable with that seen with most of the boron-containing analogs. Therefore, it does not seem that the presence of boron is critical for activity.

All of the most active analogs possessed oxygen at position 1 of the oxazolidine or oxazaborolidine ring. An exception was compound 15, which had oxygen in a different position in the ring. Compound 15 was still inhibitory, although it was clearly less effective than compounds containing oxygen at position 1; it possessed 59\% inhibitory activity at $100 \mu \mathrm{M}$ and only $17 \%$ inhibitory activity at $10 \mu \mathrm{M}$ and no activity at $1 \mu \mathrm{M}$ (Table 1). In addition, the replacement of the oxygen at position 1 with a carbonyl group, such as in phenytoin, resulted in only a $22 \%$ inhibition at $100 \mu \mathrm{M}$ (Dobrydneva and Blackmore, 2001). All of the active analogs possessed nitrogen at position 3 of the oxazolidine or oxazaborolidine ring.

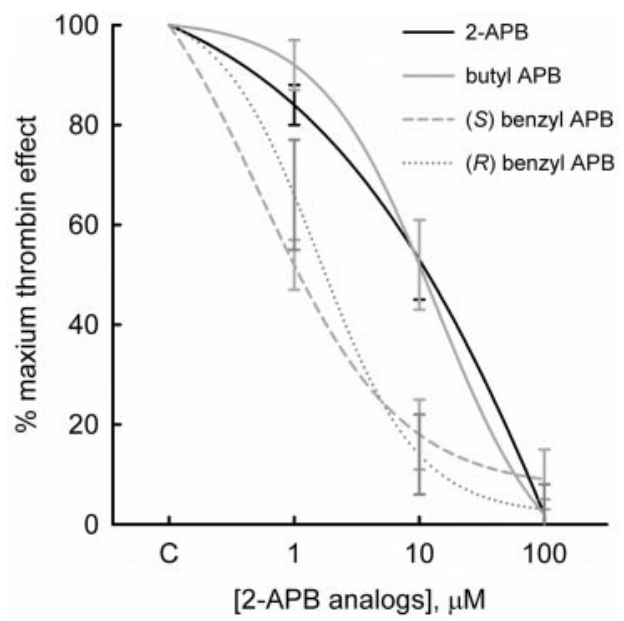

Fig. 8. Dose response of 2-APB (1), butyl APB (6), (S)-benzyl APB (11), and $(R)$-benzyl APB (12) to inhibit the ability of thrombin $(0.01$ units $/ \mathrm{ml})$ to increase $\left[\mathrm{Ca}^{2+}\right]_{\mathrm{i}}$ in platelets in the presence of extracellular calcium. Data are mean \pm S.E.M. from four separate experiments.
Methylation (2), dimethylation (3), and $t$-butylation (4) or fusing of a benzo ring to the oxazaborolidine ring at this nitrogen ( 8 and 9 ) had very little influence on activity. The addition of a phenyl group at position 5 of the oxazaborolidine ring did not influence activity at a concentration of $10 \mu \mathrm{M}(5$ and 8). At $100 \mu \mathrm{M}$, compound 8 by itself promoted calcium influx; however, at $10 \mu \mathrm{M}$, compound 8 had no effect on calcium influx by itself, but it produced a good inhibition (77\%) of thrombin, so that this compound was active. The addition of a carbonyl group at position 5 of the oxazaborolidine ring (10) drastically reduced activity.

Substitution at position 4 of the oxazaborolidine with a benzyl group (compounds 11 and 12) actually increased the calcium-blocking activity of 2-APB by approximately 1 order of magnitude. This is a curious finding because carbon 4 is a chiral center, which would place the benzyl groups in both compounds in different orientations relative to the oxazaborolidine ring. This lack of stereoselectivity between compounds could imply that there must be a large hydrophobic binding pocket that can tolerate binding of the benzyl groups when presented in two different orientations (Fig. 9).

Another feature of the boron-containing compounds presented in this study that should be considered is their ability to dimerize. However, because comparable calcium-blocking activity was also observed with carbon analogs of 2-APB (compounds 13 and 14), which cannot dimerize, dimers do not contribute to their inhibitory activity. We showed previously that diphenyl tetrahydrofuran (nonboron analog of 2-APB without a nitrogen in the tetrahydrofuran ring) possessed the ability to inhibit thrombin-induced calcium influx (Table 1 and Dobrydneva and Blackmore, 2001). This compound nevertheless was not as effective as 2 -APB at $100 \mu \mathrm{M}$; however, at lower concentrations, it was more effective than 2-APB (Table 1). Thus, the absence of nitrogen and boron did not have a deleterious effect on activity. We also tested another nonboron analog, 3,3-diphenyl dihydrofuran-2-one (compound 15). This compound was not as effective as 2 -APB and many of its analogs (Table 1). This compound contains an oxygen at position 4 and a carbonyl at position 3 (relative to oxygen in 1,3-oxazolidine); therefore, the location of the oxygen and/or the carbonyl group in the ring seems critical for activity. In addition, the absence of nitrogen in the ring may contribute to weak activity.

Because the 2-APB analogs possess the potential to dimerize and cyclize because of the formation of an $\mathrm{N} \rightarrow \mathrm{B}$ coordi-

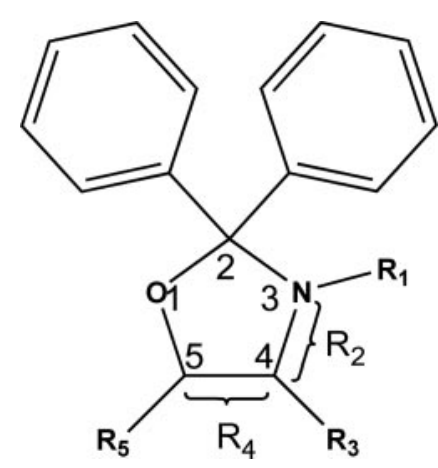

Fig. 9. Structure of diphenyl oxazaborolidine and oxazolidine rings; showing the position of each modification used in the present study. Atoms in the oxazaborolidine or oxazolidine are numbered 1 through 5 (Table 3). Substituents to the oxazaborolidine and oxazolidine rings are labeled $\mathrm{R}_{1}$ through $\mathrm{R}_{5}$ (Table 3 ). 
nate bond, it is also possible that they could also form $\mathrm{N} \rightarrow \mathrm{B}$ coordinate bonds with various amino groups in the calcium channel. The reaction between acetonitrile and diphenylborinic anhydride (Fig. 6) illustrates this phenomenon. A variety of nitrogen adducts of $\mathrm{BF}_{3}$ have been previously characterized crystallographically, and these include amines, imidazole (Barber et al., 2005; Fig. 6D), pyridine, and acetonitrile (Swanson et al., 1969; Fig. 6C) adducts (Barber et al., 2005). It is therefore conceivable that the boron analogs synthesized in the present study can also form coordinate bonds with amino acids (either $\mathrm{N} \rightarrow \mathrm{B}$ or $\mathrm{O} \rightarrow \mathrm{B}$ ). There is precedence for the boron-containing organic molecule bortezomib forming a coordinate bond with the N-terminal threonine residue of the 26S proteasome (Pekol et al., 2005). If $\mathrm{N} \rightarrow \mathrm{B}$ coordinate bonds were to occur in the cell, then these boron-containing compounds would perhaps bind more tightly to the calcium channel than their nonboron containing counterparts because of coordinate bond formation. Table 3 summarizes all of the modifications to 2-APB that were prepared and what influence they had on activity. It should be pointed out that in the present study, we have not attempted to alter the diphenyl groups to determine whether such modifications would influence activity.

This study shows that 2-APB can undergo significant modifications that have little effect on its ability to inhibit thrombin-induced $\mathrm{Ca}^{2+}$ influx in human platelets. However, we did find that two benzyl derivatives (compounds 11 and 12) were more potent than the parent 2 -APB compound. This gives us encouragement that further modifications to the 2-APB molecule can increase its potency even further. We did find previously that diphenyltetrahydrofuran (Dobrydneva and Blackmore, 2001; Table 1) produced approximately $70 \%$ inhibition of the thrombin response at $100 \mu \mathrm{M}$; however, the $\mathrm{IC}_{50}$ value was approximately $1 \mu \mathrm{M}$. Thus, diphenyltetrahydrofuran was the most potent inhibitor that we have found so far, although it was not as effective as 2-APB and many of its analogs, which produce approximately $100 \%$ inhibition at $100 \mu \mathrm{M}$ (Table 1).

As indicated by Bootman et al. (2002), 2-APB influences calcium homeostasis in a variety of cells by several different mechanisms. These include the original finding that 2-APB inhibits calcium release via $\mathrm{IP}_{3} \mathrm{Rs}$ (Maruyama et al., 1997),

\section{TABLE 3}

Summary of the modifications in the oxazaborolidine or oxazolidine ring (Fig. 9) that influence the ability of thrombin to stimulate $\mathrm{Ca}^{2+}$ influx in human platelets

The introduction of carbonyl groups or oxygen into the five-membered ring tends to decrease activity. The introduction of a benzyl on carbon 4 increased activity of the parent 2-APB molecule. There were many modifications and substitutions on the ring that could be tolerated and which had minimal effect on activity.

\begin{tabular}{clll}
\hline $\begin{array}{c}\text { Position in } \\
\text { Oxazaborolidine } \\
\text { or Oxazolidine Ring }\end{array}$ & \multicolumn{1}{c}{ Active } & \multicolumn{1}{c}{ Less Active } & $\begin{array}{c}\text { More } \\
\text { Active }\end{array}$ \\
\hline 1 & Oxygen & Carbonyl & \\
2 & Boron, carbon & Carbon, carbonyl & \\
3 & Nitrogen & $\begin{array}{l}\text { Oxygen } \\
\text { Carbonyl, oxygen }\end{array}$ & \\
4 & Carbon & & \\
5 & Carbon & & Benzyl \\
Substituent group & Methyl, dimethyl, & & \\
$\mathrm{R}_{1}$ & $\begin{array}{c}t \text {-butyl } \\
\mathrm{R}_{2}\end{array}$ & Pyridyl & \\
$\mathrm{R}_{3}$ & Ethyl, butyl & \\
$\mathrm{R}_{4}$ & Methyl, phenyl & \\
$\mathrm{R}_{5}$ & & & \\
& & & \\
\hline
\end{tabular}

although this effect is cell-specific (Soulsby and Wojcikiewicz, 2002). In addition, 2-APB also inhibits $\mathrm{IP}_{3} \mathrm{Rs}$ ubiquitination and proteasomal degradation in some cells (Soulsby and Wojcikiewicz, 2002). 2-APB has also been shown to inhibit smooth endoplasmic reticulum calcium ATPase pumps in some cells, thus causing a slow increase in $\left[\mathrm{Ca}^{2+}\right]_{i}$ (Bootman et al., 2002). In addition, 2-APB prevents mitochondria from releasing $\mathrm{Ca}^{2+}$ (Prakriya and Lewis, 2001). The best effect of 2-APB so far characterized is its ability to inhibit storemediated calcium influx in a variety of cells, including platelets (Dobrydneva and Blackmore, 2001; Bootman et al., 2002). There are many TRP channels that are inhibited by 2 -APB in the 10 to $100 \mu \mathrm{M}$ range, and these include TRPC1, TRPC3, TRPC5, TRPC6, TRPV6, TRPM3, TRPM7, TRPM8, and TRPP2 (Xu et al., 2005). Other members of the TRP channels are either activated or unaffected 2-APB. 2-APB also has been shown to modulate the store-operated calcium release-activated $\mathrm{Ca}^{2+}$ channels (e.g., Braun et al., 2001) and the $\mathrm{Mg}^{2+}$-inhibited cation channel (Kozak et al., 2002; Prakriya and Lewis, 2002).

It is of interest to compare the effects of the 2-APB analogs used in the current study on other parameters that influence $\left[\mathrm{Ca}^{2+}\right]_{i}$ in a variety of cell types. Different 2-APB analogs may have selective inhibitory or stimulatory effects on the various TRP channels, and they are likely to be very useful in elucidating the nature of the TPR channels present in various cells.

\section{References}

Azzena U, Melloni G, and Nigra C (1993) Reductive cleavage of N-substituted 2-aryl-1,3-oxazolidines: generation of alpha-amino-substituted carbanions. J Org Chem 58:6707-6711.

Bakowski D, Glitsch MD, and Parekh AB (2001) An examination of the secretion-like coupling model for the activation of the $\mathrm{Ca}^{2+}$ release-activated $\mathrm{Ca}^{2+}$ current $I_{\text {crac }}$ in RBL-1 cells. J Physiol (Lond) 532:55-71.

Barber RA, Bull AEA, Charmant JPH, Norman NC, and Orpen AG (2005) NImidazole-boron trichloride adduct. Acta Crystallogr E61:0553-o554.

Bootman MD, Collins TJ, Mackenzie L, Roderick HL, Berridge MJ, and Peppiatt CM (2002) 2-Aminoethoxydiphenyl borate (2-APB) is a reliable blocker of storeoperated $\mathrm{Ca}^{2+}$ entry but an inconsistent inhibitor of $\mathrm{InsP}_{3}$-induced $\mathrm{Ca}^{2+}$ release. FASEB J 16:1145-1150.

Braun F-J, Broad LM, Armstrong DL, and Putney JW Jr (2001) Stable activation of single CRAC-channels in divalent cation-free solutions. $J$ Biol Chem 276:10631070.

Broad LM, Braun FJ, Lievremont JP, Bird GS, Kurosaki T, and Putney JW Jr (2001 Role of the phospholipase C-inositol 1,4,5-trisphosphate pathway in calcium release-activated calcium current and capacitative calcium entry. $J$ Biol Chem 276:15945-15952.

Brownlow SL and Sage SO (2003) Rapid agonist-evoked coupling of type II Ins $(1,4,5)$ $\mathrm{P}_{3}$ receptor with human transient receptor potential (hTRPC1) channels in human platelets. Biochem J 375:697-704.

Chung MK, Guler AD, and Caterina MJ (2005) Biphasic currents evoked by chemical or thermal activation of the heat-gated ion channel, TRPV3. J Biol Chem 280: 15928-15941.

Diver JM, Sage SO, and Rosado JA (2001) The inositol trisphosphate receptor antagonist 2-aminoethoxydiphenylborate (2-APB) blocks $\mathrm{Ca}^{2+}$ entry channels in human platelets: cautions for its use in studying $\mathrm{Ca}^{2+}$ influx. Cell Calcium 30: $323-329$.

Dobrydneva Y and Blackmore PF (2001) 2-Aminoethoxydiphenyl borate directly inhibits store-operated calcium entry channels in human platelets. Mol Pharmacol 60:541-552.

Dobrydneva Y, Williams R, and Blackmore PF (2001) 2-Aminoethoxydiphenyl borinate (2APB): a direct inhibitor of $\mathrm{Ca}^{2+}$ influx channels in human platelets $(\mathrm{Ab}$ stract). FASEB J 15:A926.

Dobrydneva Y, Williams RL, and Blackmore PF (2002) 2-APB (2-aminoethoxyphenyl borate) as a prototype drug for a group of structurally related calcium channel blockers in human platelets (Abstract). FASEB J 16:A936.

Dovel B, Williams RL, Dobrydneva Y, and Blackmore PF (2002) The design, synthesis and evaluation of novel calcium channel blockers in human platelets. VA J Sci 53:86

Farfan N, Castillo D, Joseph-Nathan P, Contreras R, and Szentpaly L (1992) Through-bond modulation of $\mathrm{N} \rightarrow \mathrm{B}$ ring formation shown by NMR and X-ray diffraction studies of borate derivatives of pyridyl alcohols. J Chem Soc Perkin Trans II 4:527-532.

Gregory RB, Rychkov G, and Barritt GJ (2001) Evidence that 2-aminoethyl diphenylborate is a novel inhibitor of store-operated $\mathrm{Ca}^{2+}$ channels in liver cells and acts 
through a mechanism which does not involve inositol trisphosphate receptors. Biochem J 354:285-290.

Hu HZ, Gu Q, Wang C, Colton CK, Tang J, Kinoshita-Kawada M, Lee LY, Wood JD, and Zhu MX (2004) 2-Aminoethoxydiphenyl borate is a common activator of TRPV1, TRPV2 and TRPV3. J Biol Chem 279:35741-35748.

Iwasaki H, Mori Y, Hara Y, Uchida K, Zhou H, and Mikoshiba K (2001) 2-Aminoethoxydiphenyl borate (2-APB) inhibits capacitative calcium entry independently of the function of inositol 1,4,5-trisphosphate receptors. Recept Channels 7:429-439

Konkova SG, Badasyan AE, Khachatryan AKh, and Sargsyan MS (1999) Some questions of ring-chain tautomerism in hydroxy-containing imines. Khimicheski Zhurnal Armenii 52:16-21.

Kozak JA, Kerschbaum HH, and Cahalan MD (2002) Distinct properties of CRAC and MIC channels in RBL cells. J Gen Physiol 120:221-235.

Ma HT, Patterson RL, van Rossum DB, Birnbaumer L, Mikoshiba K, and Gill DL (2000) Requirement of the inositol trisphosphate receptor for activation of storeoperated $\mathrm{Ca}^{2+}$ channels. Science (Wash DC) 287:1647-1651.

Ma HT, Venkatachalam K, Li HS, Montell C, Kurosaki T, Patterson RL, and Gill DL (2001) Assessment of the role of the inositol 1, 4, 5-trisphosphate receptor in the activation of transient receptor potential channels and store-operated $\mathrm{Ca}^{2+}$ entry channels. $J$ Biol Chem 276:18888-18896.

Maruyama T, Kanaji T, Nakade S, Kanno T, and Mikoshiba K (1997) 2APB, 2-aminoethoxydiphenyl borate, a membrane-penetrable modulator of $\operatorname{Ins}(1,4,5) \mathrm{P}_{3}$ induced $\mathrm{Ca}^{2+}$ release. $J$ Biochem 122:498-505

Parekh AB and Putney JW (2005) Store-operated channels. Physiol Rev 85:757-810

Pekol T, Daniels JS, Labutti J, Parsons I, Nix D, Baronas E, Hsieh F, Gan LS, and Miwa G (2005) Human metabolism of the proteasome inhibitor bortezomib: identification of circulating metabolites. Drug Metab Dispos 33:771-777.

Prakriya M and Lewis RS (2001) Potentiation and inhibition of $\mathrm{Ca}^{2+}$ releaseactivated $\mathrm{Ca}^{2+}$ channels by 2 -aminoethyldiphenyl borate (2-APB) occurs independently of $\mathrm{IP}_{3}$ receptors. J Physiol 536:3-19.

Prakriya M and Lewis RS (2002) Separation and characterization of currents through store-operated CRAC channels and $\mathrm{Mg}^{2+}$-inhibited cation (MIC) channels. J Gen Physiol 119:487-507.

Redondo PC, Harper AG, Salido GM, Pariente JA, Sage SO, and Rosado JA (2004) A role for SNAP-25 but not VAMPs in store-mediated $\mathrm{Ca}^{2+}$ entry in human platelets. $J$ Physiol 558:99-109.

Rettig SJ and Trotter J (1976) Crystal and molecular structure of B,B-bis(p-toly)- boroxazolidine and the orthorhombic form of $B, B$-diphenylboroxazolidine. Can $J$ Chem 54:3131-3141.

Rosado JA, Lopez JJ, Harper AG, Harper MT, Redondo PC, Pariente JA, Sage SO, and Salido GM (2004a) Two pathways for store-mediated calcium entry differentially dependent on the actin cytoskeleton in human platelets. J Biol Chem 279:29231-29235.

Rosado JA, Redondo PC, Sage SO, Pariente JA, and Salido GM (2005) Store-operated $\mathrm{Ca}^{2+}$ entry: vesicle fusion or reversible trafficking and de novo conformational coupling? J Cell Physiol 205:262-269.

Rosado JA, Redondo PC, Salido GM, Gomez-Arteta E, Sage SO, and Pariente JA (2004b) Hydrogen peroxide generation induces pp60 ${ }^{\text {src }}$ activation in human platelets: evidence for the involvement of this pathway in store-mediated calcium entry. $J$ Biol Chem 279:1665-1675.

Rosado JA and Sage SO (2001) Role of the ERK pathway in the activation of store-mediated calcium entry in human platelets. J Biol Chem 276:15659-15665.

Soulsby MD and Wojcikiewicz RJ (2002) 2-Aminoethoxydiphenyl borate inhibits inositol 1,4,5-trisphosphate receptor function, ubiquitination and downregulation, but acts with variable characteristics in different cell types. Cell Calcium 32:175181.

Staudinger H and Freudenberger H (1943) Thiobenzophenone. Org Synth Coll Vol 2:573-574.

Swanson R, Shriver DF, and Ibers JA (1969) Nature of the donor-acceptor bond in acetonitrile-boron trihalides. The structure of boron trifluoride and boron trichloride complexes of acetonitrile. Inorg Chem 8:2182-2189.

Thadigiri C, Williams RL, Dobrydneva Y, and Blackmore PF (2003) Synthesis and evaluation of novel calcium channel blockers in human platelets. VA J Sci 54:79 van Rossum DB, Patterson RL, Ma HT, and Gill DL (2000) $\mathrm{Ca}^{2+}$ entry mediated by store depletion, S-nitrosylation and TRP3 channels. Comparison of coupling and function. J Biol Chem 275:28562-28568.

Xu SZ, Zeng F, Boulay G, Grimm C, Harteneck C, and Beech DJ (2005) Block of TRPC5 channels by 2-aminoethoxydiphenyl borate: a differential, extracellular and voltage-dependent effect. $\mathrm{Br}$ J Pharmacol 145:405-414.

Address correspondence to: Dr. Peter F. Blackmore, Department of Physiological Sciences, Eastern Virginia Medical School, P.O. Box 1980, Norfolk, VA 23501. E-mail: blackmpf@evms.edu 